\title{
Potential of microfinanced solar water pumping systems for irrigation in rural areas of Burkina Faso
}

\author{
Daniel Yamegueu ${ }^{1 *} \mathbb{D}$, Yunus Alokore ${ }^{2}$ and Giulia Corso ${ }^{3}$
}

\begin{abstract}
Background: The population in Burkina Faso is rapidly adopting irrigation to adapt to negative impacts of climate change like prolonged drought, rainfall variability and desertification. The solar water pumping systems (SWPS) could be an attractive option in view of climate change impacts, increasing diesel costs and grid electricity scarcity that the country suffers. However, due to high initial cost SWPS, population mainly uses diesel water pumps (DWPs). The main objective of this study is to assess the potential of microfinanced SWPS for irrigation in rural areas of Burkina Faso.
\end{abstract}

Methods: Based on ground data collection and profitability analysis, this study investigates the best SWPS market segments for irrigation in rural areas of Burkina Faso. The case study of the village of Korsimoro was considered. Especially, the study is focused on the onion crop as it is the most cultivated crop in the area of study.

Results: It was found that there are three main SWPS market segments in the area of study: market segment 1 which is that of farmers individually owning and using a DWP with rated power between 1.5 and $3 \mathrm{~kW}$, market segment 2 which is composed of farmers individually owning a DWP of rated power ranging from 4 to $7.5 \mathrm{~kW}$ and market segment 3 which is that of farmers paying for pumping services offered by a pump owner in market segment 2. The study revealed that replacing polyvinyl chloride (PVC) water storage tank by DWPs to be used on cloudy days is profitable for all the market segments. The study showed also that at $9.5 \%$ interest charged on agricultural equipment, only SWPS for the market segments 2 and 3 can be fully financed through microloan without risk of long payback period.

Conclusions: The results imply that more attention should be given to SWPS in the context of rural areas of Burkina Faso to enhance the productive use of energy and also mitigate the impacts of climate change on the environment. In addition, the study provides detailed information to farmers about how they can make more profitable their activities.

Keywords: Climate change adaptation, Diesel water pump, Solar water pump, Productive use of energy, Microfinance

\section{Background}

Climate change $(\mathrm{CC})$ has become a universal threat to mankind which requires urgent action. This has seen the replacement of the Millennium Development Goals (MDGs) by the Sustainable Development Goals (SDGs). The SDGs do not only target improving the social and economic life of the poor worldwide but also have

\footnotetext{
* Correspondence: daniel.yamegueu@2ie-edu.org; dan.yamegueu@gmail.com ${ }^{1}$ Renewable Energies and Energy Efficiency Laboratory, Department of Electrical, Industrial and Energy Engineering, International Institute for Water and Environmental Engineering (2iE), Rue de la science 01, BP 594, Ouagadougou 01, Burkina Faso

Full list of author information is available at the end of the article
}

additional emphasis on protecting the environment and ensuring sustainable use of resources [1]. As such, various global bodies, national governments, private businesses and households are putting concerted efforts to mitigate $\mathrm{CC}$ and adapt to its negative impacts. A study conducted by Kreft et al. to assess global CC risk index of 183 countries revealed that the developing countries where most of the poor at the bottom of the pyramid (BOP) live and are the most vulnerable to negative impacts of $\mathrm{CC}$ [2]. This is mainly because the poor at BOP have limited financial resources necessary to respond to the risks caused by $\mathrm{CC}$ as Hammill et al. 
found by assessing the role of microfinance in CC adaptation [3]. According to the authors, microfinance targets the poor population at the BOP and plays an important role in $\mathrm{CC}$ adaptation by providing financial services such as microloans, microinsurance and microsavings. The study further explains that the poor at the BOP use microloans and microsavings to acquire climate resilient techniques, accumulate assets and diversify sources of income whereas microinsurance protects from the resources acquired by the population from negative impacts of CC. The World Bank 2015 report aimed at evaluating policies and progress on ending extreme poverty revealed that as of 2015 , over 700 million people lived in extreme poverty (living on less than US\$ 1.9 per day). In addition, more than $80 \%$ of those living in extreme poverty reside in Sub Saharan Africa and South Asia [4]. In West Africa, severe variability in rainfall, prolonged drought and risk of desertification are the key CC impacts directly posing a big challenge to the livelihood of populations [5]. This directly affects agriculture on which the livelihood of more than $80 \%$ of the population depends.

In that context, solar water pumping appears as an attractive option for irrigation and drinking water as confirmed by some recent studies [6-8]. Chandel et al. study the techno-economic performances of a direct coupled photovoltaic water pumping system with a case study of an old functional solar water pumping system in a western India location. Their study found that PV-based water pumping is more cost-effective comparatively to a diesel one [6]. Arunendra et al. determined the optimum photovoltaic (PV) array configuration to supply an adequate amount of energy to a direct current (DC) helical pump, under the outdoor conditions of Nagpur in India [7]. In another study, Arunendra et al. investigated on the effect of solar radiation and total head on water output of an optimised solar water pumping system [8].

The present paper is focused on Burkina Faso which is one of the poorest Sub-Saharan countries located in West Africa. In Burkina Faso, irrigation is one of the growing $\mathrm{CC}$ adaptation methods [9]. However, it is mainly based on fossil fuel powered pumps in spite of the existing renewable energy options such as solar water pumping [10-13]. Fraiture et al. conducted a research to assess the irrigation and water management activities around Korsimoro reservoir in Burkina Faso [11]. According to the authors, the number of farmers around the reservoir adopting irrigation is on the rise. They attributed this trend to flooding of the market with cheap and portable motor pumps from China and the availability of local diesel pump technicians. A study carried out by Geslain et al. to identify the green microfinance $^{1}$ technologies and actors in Burkina Faso and Senegal revealed that capital investment for solar water pumping systems (SWPS) represents a barrier to the vulgarisation of this technology [14]. The authors hypothesised that there is a high potential of microfinanced solar water pumping for productive $u^{2} e^{2}$ in rural areas of Burkina Faso.

More generally, in previous studies abovementioned, authors addressed the technical and/or economic performances of solar water pumping systems but without in-depth analysis about the profitability of this technology relatively to the local economic context, especially the interest rate charged on agricultural equipment loans by microfinanced institutions and the payback period for these loans. Therefore, the aim of the present study is to determine the technical and economic potential of SWPS for productive use in rural areas of Burkina Faso and identify the main SWPS loan features to be developed by microfinance institutions (MFIs) with Korsimoro reservoir as the case study. Particularly, the study is based on irrigation of onion crop which is the main crop cultivated during the dry season in the area of study according to the survey conducted during this study. First, the main SWPS market segments around Korsimoro reservoir are identified. Thus, the sizing of SWPS for the main market segments around the reservoir is conducted and finally the profitability of each solar SWPS for the main market segments is assessed.

\section{Methods}

\section{Case study area}

Korsimoro reservoir is considered as a case study to represent the irrigation activities in rural areas of Burkina Faso. It was selected based on previous research which suggested that most of the irrigation practices in Burkina Faso are around the artificially constructed reservoirs rather than groundwater and other surface water sources $[10,15]$. Furthermore, many previous studies $[11,13,16]$ showed that the agricultural and water management trends around all the reservoirs in Burkina Faso are similar. Therefore, as one of the largest among the 1300 artificially constructed reservoir in Burkina Faso, the activities around Korsimoro reservoir were considered to be representative of irrigation in rural areas of Burkina Faso. Table 1 summarises key information about the activities of farmers around the reservoir.

According to Fraiture et al., the reservoir was initially constructed for irrigating rice plantations downstream [11]. Currently, the area occupied by the vegetables upstream is more than that of rice plantations. Especially, the onions grown around the reservoir are sold either within Burkina Faso or in the neighbouring countries such as Ghana and Ivory Coast. The farmers use motor pumps either shared or individuals to pump water from the reservoir into their farms directly or into ditches which allow the water to flow by gravity [11]. The increase in the use of diesel water 
Table 1 Korsimoro reservoir cropping pattern and irrigation technologies $[11,13,15,16]$

\begin{tabular}{ll}
\hline Reservoir & Attributes \\
\hline Year of construction & 1984 \\
Location & $70 \mathrm{~km}$ northeast of Ouagadougou \\
Capacity & $4.7 \mathrm{million}^{3}$ \\
Agroecological zone & South Sahelian zone \\
Water users & (1) Vegetable, (2) rice, (3) pastoralist, (4) fishermen \\
Crops & \\
$\begin{array}{l}\text { Upstream } \\
\text { Downstream crop }\end{array}$ & 1000 farmers sharing 230 ha \\
Crop cycles & Rice 32 ha \\
Current pumps used & 2 cycles in dry season: Oct to Dec and Jan to Apr \\
Technology & \\
Shared pumps & Kerosene, petrol, diesel pumps \\
Market availability of pumps & 5-10 Hp diesel (brands Kirloskar/Rhino) \\
\hline
\end{tabular}

pumps (DWPs) was attributed to the flooding of the market with cheap pumps from China and India $[11,15]$. The ease to find local technicians to repair the motor pumps also promotes their use.

\section{Data collection}

The present study mainly used ground data collection from a survey conducted in the case study area. The target group was the farmers around Korsimoro reservoir. After the survey, a focus group discussion was conducted for data verification. Due to financial and time constraints, the entire population of farmers in Korsimoro was not surveyed but rather a representative sample of farmers was randomly selected. The sample size was determined using Formula (1) recommended by Charan et al. [17].

$$
\text { Sample size }=\frac{\mathrm{Z}_{\alpha / 2}^{2} \times p \times(1-p) \times D}{d^{2}}
$$

where $P$ is the prevalence or proportion of event of interest for the study, and $d$ is the margin of error; $P$ is generally obtained based on previous literature. Generally, $d$ is equal to $10 \%$ of $P$ and $Z \alpha / 2$ is the normal deviate for two-tailed alternative hypothesis at a level of significance; for example, for $5 \%$ level of significance, $Z_{\alpha /}$ ${ }_{2}$ is 1.96 and for $1 \%$ level of significance it is 2.58 . $D$ is the design effect reflects the sampling design used in the survey type of study. This is 1 for simple random sampling and higher values (usually 1 to 2 ) for other designs such as stratified, systematic and cluster random sampling, estimated to compensate for deviation from simple random sampling procedure.

\section{Sizing of the solar water pumping systems}

Given the huge number of farmers, it was a complex process to size for each of them as such the sizing was done for the main market segments. The area of land cultivated with different crops by farmers in the different market segments was measured using global positioning system (GPS). Due to diversity in the crops grown by around the reservoir, the sizing was done only for onion crop which is the main crop grown in dry season as shown in the section on results. The different variables for sizing the SWPS such as irrigation water requirement (IWR), pump flow rate, size of water storage, and excess energy alternative use in case of no irrigation were determined for the different market segments.

\section{Determining irrigation water requirement}

The irrigation water requirements (IWR) and schedules were determined using CROPWAT 8.0 which is an open source computer program available on http://www.fao.org/ land-water/databases-and-software/cropwat/en/ and which was developed by Food and Agriculture Organisation (FAO) [18]. CROPWAT 8.0 uses the Penman-Monteith model shown by Formula (2) to determine reference crop evapotranspiration $\mathrm{ET}_{\mathrm{O}}$ and subsequently the crop water requirement (CWR) and IWR using Formula (3) and Formula (4) respectively [19].

$$
\begin{aligned}
& \mathrm{ET}_{\mathrm{o}}=\mathrm{ET}_{\text {wind }}+\mathrm{ET}_{\mathrm{rad}} \\
& \mathrm{CWR}=\mathrm{K}_{\mathrm{c}} \times \mathrm{ET}_{\mathrm{o}} \\
& \mathrm{IWR}=\mathrm{CWR}-\text { Rain }_{\text {eff }}
\end{aligned}
$$

where $\mathrm{ET}_{\mathrm{o}}$ is the reference crop evapotranspiration in $\mathrm{mm} /$ day, $\mathrm{ET}_{\text {rad }}$ and $\mathrm{ET}_{\text {wind }}$ are the contributions of solar radiation and aerodynamic (wind and humidity) to $\mathrm{ET}_{\mathrm{o}}$ 
respectively, CWR is the crop water requirement, $K_{\mathrm{c}}$ is the crop factor, IWR is irrigation water requirement

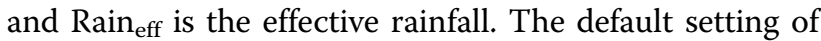
CROPWAT 8.0 stating that net IWR is $70 \%$ of the gross IWR was maintained in this study.

CROPWAT 8.0 has been used by various researchers to calculate CWR, IWR and for irrigations schedules $[19,20]$.

The climatic data used for this study were obtained from CLIMWAT 2.0. Data of Ouagadougou was used since it is the nearest weather station to Korsimoro and the two areas are in the same agroecological zones. Other variables necessary for calculating the IWR such as length of crop growth periods and crop factor $K_{\mathrm{c}}$ were according to Wang et al. [20]. The soil data such as infiltration rate, total available moisture and initial available moisture of red sandy soil for this study was based on the findings of the previous study by Ndanga et al. on the state of agricultural water management in Korsimoro reservoir [12].

\section{Determining total dynamic head (TDH)}

The total dynamic head (TDH) is the overall vertical height the pump has to overcome. The TDH is composed of static head $S_{\mathrm{L}}$, frictional loss $F_{\mathrm{P}}$ on pipe walls and the frictional loss $F_{\mathrm{F}}$ due to fittings. Principally, the TDH is calculated based on Formula (5) [21].

$$
\mathrm{TDH}=S_{L}+F_{\mathrm{P}}
$$

The frictional losses in a pipe depend on the flow rate, length of pipe, nominal diameter of pipe and pipe material. Furthermore, the relationship developed by Hazen-William can be used to determine the friction on the pipe walls. Formula (6) shows the Hazen-William relationship as used by Jenkins for determining friction in pipes [21].

$$
F_{\mathrm{P}}=\frac{10.67 \times Q^{1.852}}{D_{\mathrm{h}}^{4.8655} \times C^{1.852}} \times L
$$

where $F_{\mathrm{P}}$ is head loss due to friction in metres, $Q$ is the pump flow rate in $\mathrm{m}^{3} / \mathrm{s}, D_{\mathrm{h}}$ is the inside hydraulic diameter of pipe in metres, $L$ is the pipe length in metres and $C$ is the roughness coefficient.

\section{Determining pump flow rate}

The pump flow rate $Q$ is the amount of water delivered by the pump within a set time. Formula (7) is used by Jenkins et al. and Nisa et al. in designing of SWPS [21, 22].

$$
Q=\frac{\text { IWR }}{3600 \times \mathrm{H}_{\mathrm{p}}}
$$

where $Q$ is the pump flow rate in $\mathrm{m}^{3} / \mathrm{s}$, IWR is the irrigation water requirement in $\mathrm{m}^{3} /$ day and $H_{\mathrm{P}}$ is the peak sunshine hours per day in hours/day. To supply the required flow rate $Q$, the pump should overcome the hydraulic load usually referred to as hydraulic workload.

\section{Selection of pump}

The pumps for each of the three segments of farmers were selected based on the $Q$ and TDH calculated. The specifications of the selected pump such as pumping efficiency $\eta_{\mathrm{B}}$, maximum operation voltage $V_{\mathrm{S}}$ and current $I_{M}$ were read from the user manuals and used in the sizing of the PV array.

\section{Sizing of solar array}

The solar PV array converts sunlight into direct current, and energy supplied by the solar PV array should be enough to support the pump. Sizing of the PV array involved determining the power and number of modules. The power of the PV array was calculated based on Formula (8) as used by Jenkins in designing solar water pumps for livestock [21].

$$
P=\frac{\rho \times g \times \mathrm{TDH} \times Q}{\eta_{\mathrm{P}} \mathrm{PR}}
$$

where $P$ is the minimum power in $\mathrm{Wp}, Q$ is the irrigation water requirement discharge in $\mathrm{m}^{3} / \mathrm{s}$ at the total dynamic head TDH in metres, $\rho$ is the density of water in $\mathrm{Kg} / \mathrm{m}^{3}, g$ is the acceleration due to gravity in $\mathrm{m} / \mathrm{s}^{2}, \eta_{P}$ is the efficiency of the pumping system and PR is the performance ratio of the PV array. PR is between 0.75 and 0.85. To determine the number of PV modules in the array, the number of PV modules in series and parallel were determined.

Photovoltaic modules are connected in series to increase their voltage so as to achieve the operating voltage $V_{\mathrm{S}}$ of the selected pump. The number of PV modules in series was calculated using Formula (9) [21].

$$
N_{\mathrm{s}}=\frac{V_{\mathrm{S}}}{V}
$$

where $N_{\mathrm{S}}$ is the number of PV modules in a string, $V_{\mathrm{S}}$ is the operating voltage of the pump and $V$ is the voltage of each PV module. The strings of PV modules are connected in parallel to ensure that the current from the PV array meets the current required by the selected pump. The number of PV strings in parallel, $N_{\mathrm{p}}$, was determined using Formula (10) [21].

$$
N \mathrm{p}=\frac{P}{V_{\mathrm{s}} \times I_{\mathrm{M}}}
$$

where $N_{\mathrm{p}}$ is the number of PV module strings in parallel, $P$ is the power produced by the PV array in watts, $V_{\mathrm{S}}$ is the operating voltage of the selected pump, $I_{M}$ is the operating current of each PV module. 
The total number of PV modules in the array is then obtained by using Formula (11).

$$
N=N_{\mathrm{s}} \times N_{\mathrm{p}}
$$

where $N$ is the total number of PV modules in the array, $N_{\mathrm{s}}$ is the number of PV modules in a string and $N_{\mathrm{P}}$ is the number of PV strings in parallel. Agronomic practice recommends that the irrigation be done in the evening or morning when the sun is not shining to minimise water losses due to evaporation [23]. This therefore requires the water to be stored for use in the forementioned periods or cloudy days.

\section{Sizing of water storage tank}

The storage tank is used to store water in overcast days or when the crops are not being irrigated. The size of the water storage was determined using Formula (12). The tank type was selected based on the availability in the local market, durability and expertise required for installation, initial price and maintenance costs. In this study, polyvinyl chloride (PVC) tank is used as it is the one most available on the local market. It is imported from Ghana, a neighbouring country is currently used by most of the farmers. It is also of a better quality compared to those made locally with steel or concrete.

$$
\mathrm{WST}=\mathrm{IWR} \times \mathrm{OD}
$$

where WST is the capacity of water storage in $\mathrm{m}^{3}$, OD is the number of days of autonomy and IWR is the irrigation water requirement $\mathrm{m}^{3} /$ day. According to [24], in Ouagadougou, $^{3} 69.2 \%$ of the days are sunny and $30.8 \%$ are cloudy. For this study, OD was assumed to be 1 day.

\section{Determining excess energy for alternative use}

During the period of crop harvest and when the effective rain is sufficient to meet the CWR, the SWPS is not used for irrigation. The excess energy $\boldsymbol{E}_{\mathbf{P V}}$ produced by the PV array for alternative use was calculated through Formula (13) [25].

$$
E_{\mathrm{PV}}=P \times \frac{G}{G^{\prime}} \times\left(1+\alpha_{T}\left(T_{\alpha}-T_{\text {ref }}\right)\right) \times \eta_{\mathrm{I}}
$$

where $E_{\mathrm{PV}}$ is the energy produced by the PV array in kWh, $P$ is the installed capacity of the PV array in Wp, $G$ is the global monthly average daily solar radiation in $\mathrm{Wh} / \mathrm{m}^{2} /$ day, $G^{\prime}$ is the watt peak which is usually 1000 $\mathrm{W} / \mathrm{m}^{2}, \alpha_{T}$ is the temperature coefficient of the selected PV modules as indicated by the manufacturer, $T_{\alpha}$ and $T_{\text {ref }}$ are the ambient temperature and temperature at STC respectively and $\eta_{I}$ is the inverter efficiency.

\section{Determining profitability of solar water pumps}

Profitability of SWPS for different segments of farmers was determined based on net present value (NPV) and payback period (PBP) economic tools. Net present value and payback period have been used in different studies to determine the profitability of both small and large off grid and on grid Clean Energy Technology (CET) projects [26-28]. The details of the methods are displayed below.

\section{Net present value}

The use of net present value (NPV) as a way of assessing the profitability of renewable energy technologies was recommended by Hosenuzzaman et al. in a research to assess the global perspectives and impacts of solar PV systems [28]. The final equation for NPV can be written as shown in Formula (14) [28].

$$
\mathrm{NPV}=\sum_{t=1}^{N} \frac{\mathrm{CF}_{\mathrm{t}}}{(1-\mathrm{i})^{\mathrm{N}}}-C
$$

where NPV is the net present value, $N$ is the lifespan of SWPS in years, $C F_{t}$ is the cash flow in the $t^{\text {th }}$ year in US\$, $C$ is the capital cost in US\$ and $i$ is the discounting rate.

\section{Payback period}

Payback period (PBP) is the time over which the capital investment of a business venture can be recovered. The payback periods for the different SWPS market segments were calculated using Formula (15) [26, 27].

$$
\mathrm{PBP}=\frac{\log \left(1-\frac{C}{\mathrm{CF}_{t}} \times \mathrm{i}\right)}{\log \left(\frac{1}{1+i}\right)}
$$

where PBP is the discounted payback periods, $C$ is the capital cost of SWPS, $C_{\mathrm{t}}$ is the cash flow at any time $t$ and $i$ is the discounting rate.

\section{Internal rate of return}

Internal rate of return refers to the maximum interest above which the SWPS will not be profitable as illustrated by Treephak et al. in a research to compare SWPS and DWP for irrigation [29]. According to the study, Formula (16) can be used to determine the internal interest rate.

$$
\sum_{t=1}^{N} \frac{\mathrm{CF}_{\mathrm{t}}}{(1-\mathrm{IRR})^{N}}-C=0
$$

where IRR is the internal rate of rate, $N$ is the lifespan of SWPS in years, $C_{\mathrm{t}}$ is the cash flow in the $t^{\text {th }}$ year, $C$ is the capital cost and $i$ is the discounting rate. 


\section{Determining the interest rate}

Research carried out by SEEP to assess the transparency of microfinance sector in Burkina Faso found that the sector is monitored nationally by Ministry of Economy and Finance and regionally by the Central Bank of West African States (BCEAO) as it does for other seven countries under West African Economic and Monetary Union (WAEMU) [30]. According to [30], the maximum interest rate set by WAEMU for MFIs is $24 \%$ per year. The interest was selected in a way that it should not exceed the cap set by WAEMU and the IRR of the technology. For the selected frequency of payment, the effective interest rate was calculated using Formula (14).

$$
i_{e}=\left(i_{n}+1\right)^{1 / n}-1
$$

where $i_{e}$ is the effective interest rate charged per interest period, $i_{n}$ is the nominal interest rate per year and $n$ is the number of interest periods in a year.

\section{Results and discussion}

Seasons of crop cultivation around Korsimoro reservoir In the present study, by considering a simple random study, assuming $95 \%$ confidence interval or $5 \%$ level of significance and $10 \%$ margin of error, and basing on the findings of a previous study by Fraiture et al. [11] allowing to obtain the estimates of $P$ at $81.5 \%$, a minimum sample size of 87 farmers was obtained. But $10 \%$ of this calculated value was added to get the actual number of farmers to be surveyed. Thus, a final adjusted sample size of 96 farmers was obtained by applying the margin error of $10 \%$. Thus, 96 farmers were randomly selected and surveyed during this study.

The study area experiences two seasons per year (dry season and rainy season). Figure 1 shows the classification of the 96 farmers surveyed based on the season(s) in which they cultivate crops. As shown in Fig. 1, the study found that out of the 96 farmers surveyed 45 (46.9\%) of them cultivate in both seasons (dry and rainy), $32(33.3 \%)$ in rainy season only and 18 (18.8\%) in dry season only. The farmers who cultivate in dry season only have an alternative source of income which they focus on during the rainy season.

Additionally, the study found that $67 \%$ of the farmers irrigate their crops at least in one of the two seasons and $33 \%$ do not irrigate the crops at all.

Figure 2 shows the land area under different crops cultivated around the reservoir in rainy and dry seasons.

Overall, the surveyed farmers covered 22.1 ha of which 17.72 ha was cultivated in the rainy season and 14.52 ha in the dry season. In the rainy season, $77 \%$ of the land was occupied by grains (sorghum 28\%, rice 19\%, millet $21 \%$ and other grains $9 \%$ ) and $23 \%$ under vegetables (onions $4 \%$, tomatoes $5 \%$, cabbage $2 \%$, eggplant $6 \%$, pepper
$4 \%$ and other vegetable $2 \%$ ). On the other hand, in the dry season, vegetables dominated the land cultivated at $89 \%$ (onions $32 \%$, tomatoes $14 \%$, cabbage 19, eggplant $9 \%$, pepper $11 \%$ and other vegetables $4 \%$ ) and grains occupy $11 \%$ (sorghum $2 \%$, rice $4 \%$, millet $1 \%$ and other grains $5 \%$ ). This trend is because grain crops can survive the drought between rains in the rainy season but vegetable have higher yield response factor compared to grain crops. The farmers understand that vegetables would still need some irrigation in the rainy season.

\section{SWPS market segments}

The types of pumps used around Korsimoro reservoir were classified according to their rated power for purpose of identifying the main segments of farmers for which the solar water pumps could be sized. It was found that of the 48 pumps counted, $46 \%$ were individually owned, $23 \%$ were shared pumps and for $31 \%$ of the pumps, other forms of ownership such as hiring and borrowing without having to pay the owner among others. Based on that classification, three main market segments for SWPS were identified. Table 2 shows the specifications of the common DWPs used for irrigation around Korsimoro reservoir.

Each of the segment is described below:

- Market segment 1 is that of farmers individually owning and using a DWP with rated power between 1.5 and $3 \mathrm{~kW}$. In the present study, this market segment is represented by the farmers currently using $2.6 \mathrm{~kW}$ Robin/Koshin pumps whose characteristics are described in Table 2 . The savings of this market segment were calculated according to irrigation frequency and duration of irrigation summarised in Table 3. From the survey, it was found that the farmers in this market segment have fields occupying an average area of $10,350 \mathrm{~m}^{2}$.

- Market segment 2 is composed of farmers individually owning a DWP of rated power ranging from 4 to $7.5 \mathrm{~kW}$ and using it to provide pumping services to a group of farmers at a fee. In the present study, this market segment 2 is represented by a group of farmers sharing $5.5 \mathrm{~kW}$ Rhino/Kirloskar DWP with properties shown in Table 2. The savings of this market segment were calculated according to irrigation frequency and duration of irrigation summarised in Table 3. From the survey, it was found that on average a group of farmers in market segment 2 occupy $28,770 \mathrm{~m}^{2}$ of land.

- Market segment 3 is that of a farmer cultivating on $400 \mathrm{~m}^{2}$ piece of land and paying for pumping services offered by a pump owner in market segment 2. During the focus group discussion, it was found that the farmers in market segment 3 pay a 


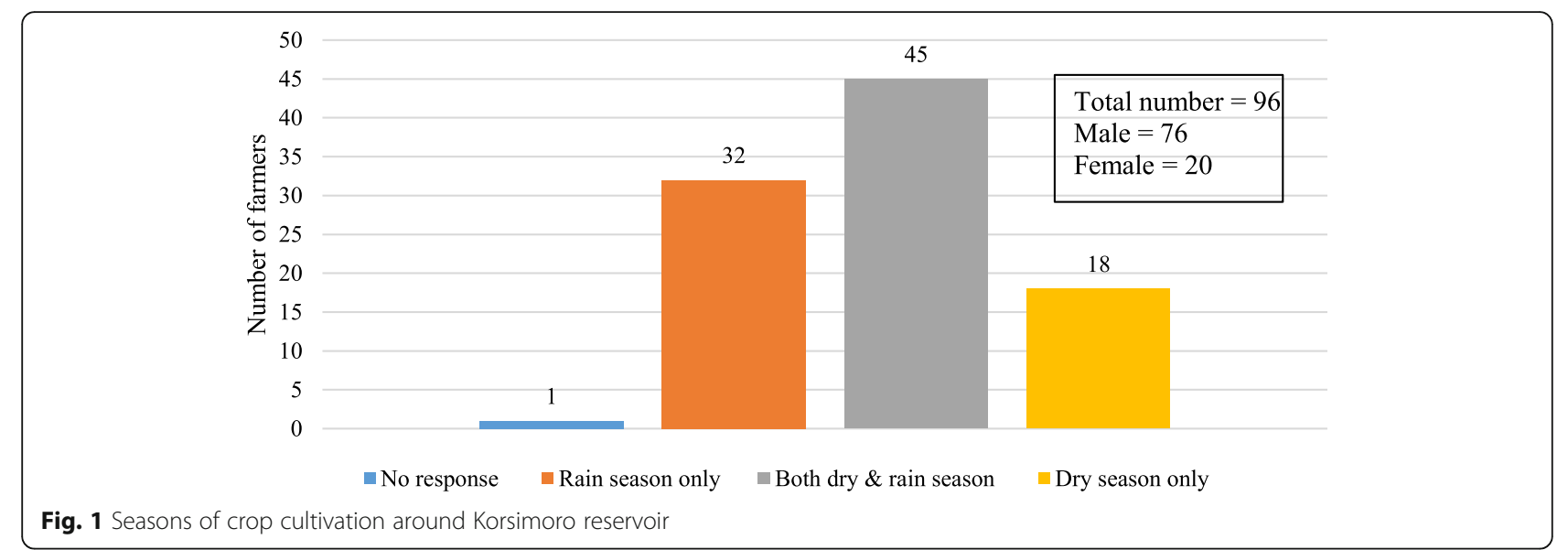

fee of US\$ 44.5 per crop cycle to a pump owner in market segment 2 for pumping services.

For each market segment, both AC and DC systems with water storage were sized. The sizing of the components of SWPS was done using Formula (7) to Formula (12). In the proceeding sections of this research, the following naming of the SWPS will be used:

- Market segment 1 AC SWPS: solar water pumping system for market segment 1 based on AC pump with polyvinyl chloride (PVC) water storage

- Market segment 1 DC SWPS: solar water pumping system for market segment 1 based on DC pump with PVC water storage

- Market segment 2 AC SWPS: solar water pumping system for market segment 2 based on AC pump with PVC water storage

- Market segment 2 DC SWPS: solar water pumping system for market segment 2 based on DC pump with PVC water storage
- Market segment 3 AC SWPS: solar water pumping system for market segment 3 based on AC pump with PVC water storage

- Market segment 3 DC SWPS: solar water pumping system for market segment 3 based on DC pump with PVC water storage

\section{Attributes for sizing SWPS for the main market segments}

This section contains findings of the research such as irrigation water requirement (IWR) and pump flow rate $(Q)$ which are used to select pumps, water tank storage and to size the PV array and PV inverters of the different systems. As already mentioned above, in this study, the sizing of the components of SWPS was based on onion crop since it is the dominant crop cultivated in the dry season as shown in Fig. 2.

\section{Irrigation water requirement}

This subsection covers the irrigation water requirement (IWR) characteristics of onion crop according to the

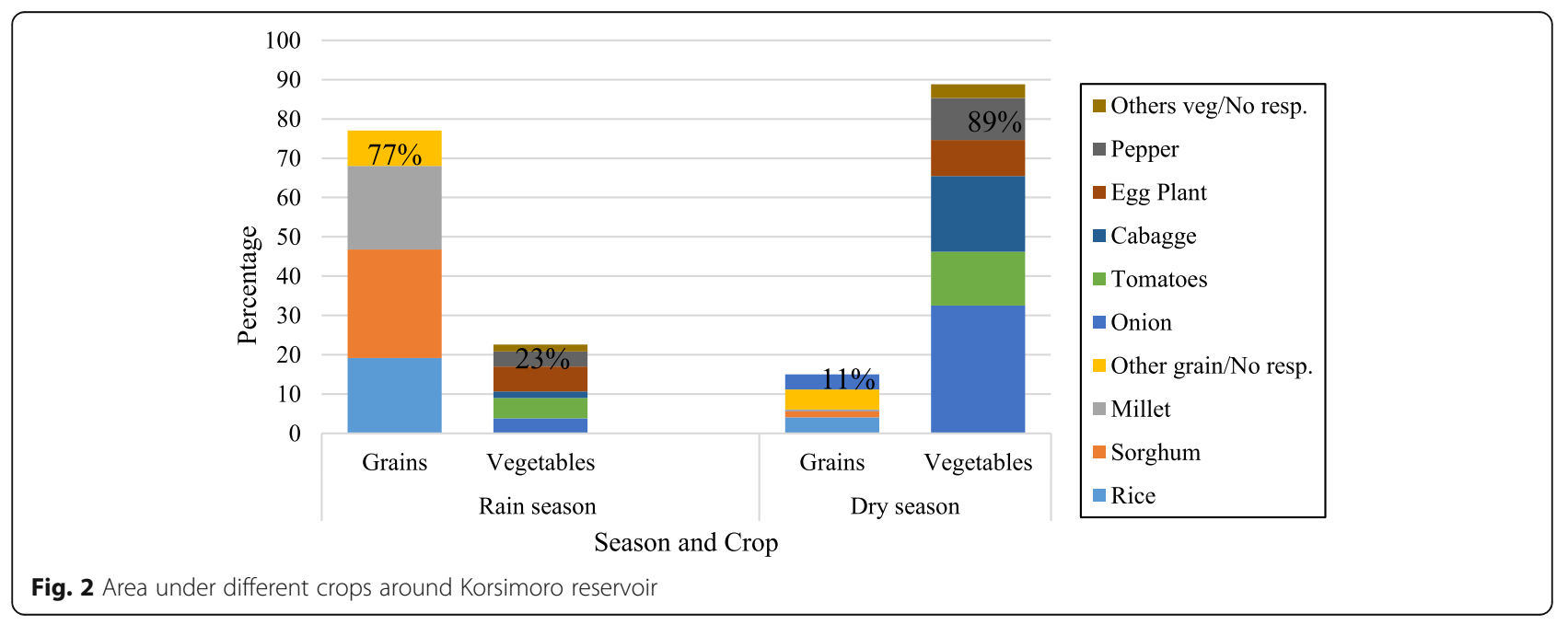


Table 2 Pumps used around Korsimoro reservoir

\begin{tabular}{llllll}
\hline Brand & Rated power $(\mathrm{kW})$ & Flow rate $(\mathrm{l} / \mathrm{s})$ & TDM $(\mathrm{m})$ & Diameter $(\mathrm{mm})$ & $\mathrm{N}=48$ \\
\hline Rhino/Kirloskar & 5.9 & 26.0 & 14.5 & 95.5 & 80 \\
Robin/Koshin & 2.6 & 15.5 & 26 & 76 & 21 \\
Honda & 3.9 & 7.0 & 25 & 6 \\
Others/no response & & & & 11 \\
\hline
\end{tabular}

stages of growth and climatic conditions. For this analysis, four successive crop cycles each lasting 90 days were considered in a year as found by Wang et al. in a study on agricultural water management in Burkina Faso [20].

Based on the findings showing that the farmers shift from cultivating grain crops to vegetables at the beginning of the dry season, October was taken as the start of the first crop cycle. Figure 3 shows the effective rainfall, CWR and IWR of onion crop in Ouagadougou as generated using the software CROPWAT 8.0.

The IWR is the difference between crop water requirements (CWR) and the effective rain depicted by Formula (4) [23]. Figure 3 shows that a combination of the maximum CWR and minimum effective rainfall results into maximum IWR and this occurs between December and April. Within this period, the entire CWR is supplied through irrigation. At the end of April and beginning of May, the IWR of the crop in the initial and development stages of cycle 3 is substantially high. However, the IWR starts to decrease in mid-May to the end of the crop cycle 3 at end of June. This is partly because the rainy season starts mid-May and subsequently the effective rainfall increases. Crop cycle 4 is from the beginning of July through to the end of September. Generally, the IWR of the crop in crop cycle 4 is low with the maturity and late stages of the crop not requiring any irrigation at all. This is because effective rainfall towards the end of August and beginning of September is either equal to or high than the CWR.

\section{Pump flow rates}

This section contains the pump flow rates $(Q)$ necessary to meet the IWR of the three SWPS market segments. As shown in Fig. 3, the IWR depends on the climatic conditions and crop growth stage. According to Doorenbos and Kassam in [31], since IWR varies throughout the year, the focus should be on the maximum IWR so as to cater for all the other days in the crop cycle. From CROPWAT 8.0, the maximum IWR for the four crop cycles was found as $104.4 \mathrm{~m}^{3} /$ day/ha which occurs in April. The average area cultivated by farmers in each market segment was multiplied by the $104.4 \mathrm{~m}^{3} /$ day/ha calculated using CROPWAT 8.0. Table 4 shows the pump flow rates necessary to meet the maximum IWR of each market segment.

As one can notice, market segment 2 has the highest $Q$, followed by market segment 1 and lastly market segment 3 . This is because farmers in market segment 2 cultivate the largest average area compared to the market segment 1 and 3 .

\section{Sizing of SWPS for the main market segments}

SWPS were sized for the three market segments so as to meet the irrigation water requirement. The assumption for calculating the storage was that there is 1 day of autonomy and this assumption was applied for calculating water storage for all the other market segment. The final choice of pumps and inverters have been made according to what available on the local market.

Six SWPS were sized for the three markets segments around Korsimoro reservoir. For each market segment, an AC and a DC system were sized. Table 5 summarises the six systems obtained after the sizing process.

The technical specifications of selected PV pumps are gathered in Table 6.

In the next sections, the profitability of $\mathrm{DC}$ and $\mathrm{AC}$ systems will be compared for each market segment.

\section{Profitability analysis}

The costs of the main equipment used for the calculations are gathered in Table 7.

Interest rate of $5.3 \%$ per year was considered for the calculations. It is a nominal interest rate calculated as the sum of marginal interest rate $4.5 \%$ and year-on-year inflation rate of $0.8 \%$ provided by the West Africa Central Bank (BCEAO) [32].

In total, profitability analysis was conducted for nine SWPS. For each of the three SWPS market segments, three systems were compared. The profitability analysis

Table 3 Existing duration of pumping and frequency of irrigation

\begin{tabular}{|c|c|c|c|c|}
\hline \multirow[t]{2}{*}{ Pumps } & \multicolumn{2}{|c|}{ Average duration of pumping (hrs) } & \multicolumn{2}{|c|}{ Frequency of irrigation } \\
\hline & Dry season & Rainy season & Dry season & Rainy season \\
\hline Individually owned 2.6 kW Robin/Koshin & 10.6 & 5.5 & After 3 days & After 5 days \\
\hline Shared 5.9 kW Rhino/Kirloskar & 12 & 5 & After 3 days & After 5 days \\
\hline
\end{tabular}




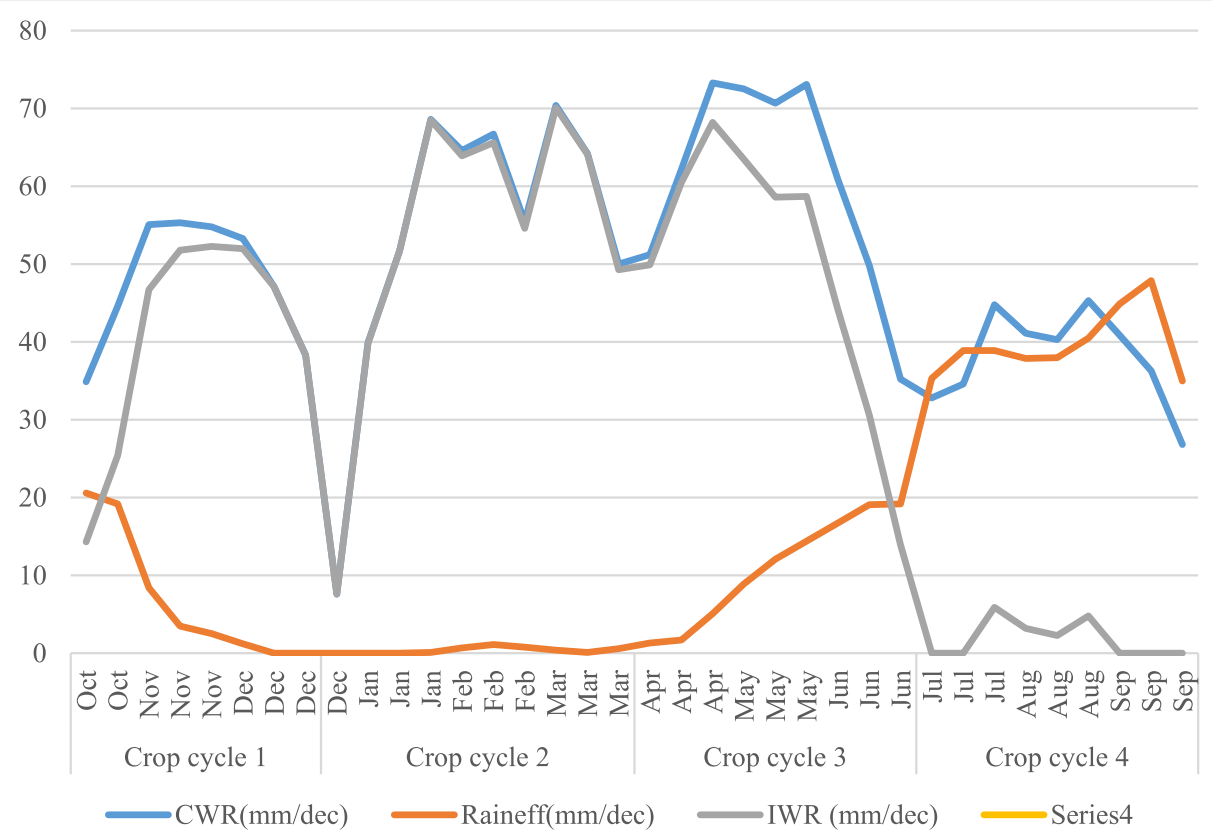

Fig. 3 Irrigation water requirement characteristics of onion crop

was conducted in two stages. In the first analysis, for each of three SWPS market segments, AC and DC systems with water storage were analysed for complete replacement of existing DWPs. From the first stage of profitability analysis, between $\mathrm{AC}$ and $\mathrm{DC}$, for each SWPS market segment, the system with higher IRR was selected and further analysed was conducted when water storage is replaced by DWP to be used on cloudy days. Table 8 summarises the nine systems assessed.

One can notice that, for all the market segments, SWPS with water storage is not profitable except market segment 3 DC SWPS. However, SWPS is profitable for all the three market segments when water storage is replaced with DWP to be used on cloudy days. At an interest rate of $5.3 \%$ per year, market segment $3 \mathrm{DC}$ SWPS/DWP has the shortest PBP of 7 years, followed by 10.1 years for market segment 2 AC SWPS/DWP and lastly 11.3 years for market segment 1 AC SWPS/DWP. In case the SWPS are financed through a loan scheme, the interest rate charged should not exceed the IRR shown in Table 8 for the systems to remain profitable. According to World Food Programme (WFP) 2016 report on financial inclusion, FCPB provides agricultural loans to farmers at an interest rate of $9.5 \%$ per year compared to between 12 and 14\% charged by most financial service providers in Burkina Faso [33]. Based on the forementioned interest rates, the PBPs of the three SWPS without storage were calculated using Formula (14). Table 9 shows the PBP of SWPS at various interest rates charged by MFIs in Burkina Faso.

As shown in Table 9, when the SWPS are financed through a loan of $9.5 \%$ per year, they all have PBP below 20 years, implying that the farmers can recover their investment prior to the life span of the system. However, with a PBP of 18.5 and 15 years respectively for market segment 1 AC SWPS/DWP and 2 AC SWPS/DWP, one can perceive that financing the system through loan at 9.5\% exposes the farmer to risks due to long PBP. Probably, this will require that these two market segments be partly financed through a grant or else farmers should use other microfinance services such as savings so as to reduce the cost of financing the project. At an interest rate of $12 \%$ and $14 \%$ per year, only the investment in market segment $3 \mathrm{AC}$ SWPS/DWP and market segment 3 DC SWPS/DWP is recoverable before 20 years. One can observe that market segment 3 DC SWPS/DWP can

Table 4 Daily water requirement and flow rate

\begin{tabular}{llll}
\hline DWR and Q & Market segment 1 & Market segment 2 & Market segment 3 \\
\hline Average area (ha) & 1.035 & 2.877 & 0.04 \\
Max DWR $\left(\mathrm{m}^{3} /\right.$ day $)$ & 108.054 & 300.324 & 4.176 \\
$\mathrm{Q}\left(\mathrm{m}^{3} / \mathrm{s}\right)$ & 0.00507 & 0.01410 & 0.00020 \\
$\mathrm{Q}\left(\mathrm{m}^{3} / \mathrm{hr}\right)$ & 18.3 & 50.8 & 0.7 \\
\hline
\end{tabular}


Table 5 Summary of the SWPS with water storage for Korsimoro

\begin{tabular}{|c|c|c|c|c|c|c|}
\hline \multirow{2}{*}{$\begin{array}{l}\text { System } \\
\text { component }\end{array}$} & \multicolumn{2}{|c|}{ Market segment 1} & \multicolumn{2}{|c|}{ Market segment 2} & \multicolumn{2}{|c|}{ Market segment 3} \\
\hline & $A C$ & $\mathrm{DC}$ & $A C$ & DC & $A C$ & DC \\
\hline Pump (W) & 2200 & 3000 & 3000 & 4000 & 120 & 120 \\
\hline Inverter (W) & 2500 & - & 3500 & - & 180 & - \\
\hline Tank size $\left(\mathrm{m}^{3}\right)$ & 100 & 100 & 300 & 300 & 5 & 5 \\
\hline PV array (Wp) & 2800 & 4000 & 3800 & 5000 & 200 & 160 \\
\hline
\end{tabular}

be profitably financed through loan at an interest rate of up to $14 \%$ without exposing the farmer to risk as a result of long PBP beyond 10 years.

Therefore, the most suitable interest rate to be used for financing the SWPS/DWP is $9.5 \%$ per year. At this interest rate, the market segment 3 DC SWPS/DWP and in certain extent market segment $2 \mathrm{AC}$ can be fully financed through a loan without exposing the farmer to the risk of losing his investment due to long PBP beyond 15 years. During the focus group discussion, it was found that the farmers' associations in the study area lend loans to farmers at an interest rate of $10 \%$ per crop cycle (3 to 6 months). The selected interest rate of 9.5\% per year for SWPS is less than the one currently charged by the farmers' associations. As such, we perceive that the farmers will easily understand and adopt it. Lastly, the selected interest rate of $9.5 \%$ per year is below $24 \%$ per year cap set by WAEMU [30].

\section{Conclusions and further works}

This study aimed at assessing the potential of microfinanced solar water pumping for productive use in rural areas of Burkina Faso with Korsimoro reservoir as a case study. First, a survey and focus group discussion were conducted in the village of Korsimoro to identify the main market segments for SWPS. Then, CROPWAT 8.0 software was used to analyse the data and sizing SWPS for the market segments identified comparing $\mathrm{AC}$ and DC systems was made. Finally, cash flow analysis was performed to determine the profitability of SWPS when used with and without water storage for each market segment.

The study found that there are three main SWPS market segments around Korsimoro reservoir. Market segment 1 is that of farmers currently cultivating $10,350 \mathrm{~m}^{2}$ on average and individually owning and using DWP of rated power between 1.5 and $3.0 \mathrm{~kW}$. Market segment 2 comprises of farmers currently owning DWPs of rated power between 4 and $7.5 \mathrm{~kW}$ and using them to provide pumping services to a group of farmers at a fee. The average size of combined land cultivated by a group of farmers sharing a pump in market segment 2 is $28,767 \mathrm{~m}^{2}$. Lastly, market segment 3 consists of farmers paying a fee to a pump owner in market segment 2 for the pumping services. Market segment 3 is represented in this study by a farmer cultivating $400 \mathrm{~m}^{2}$ of land. For each of the three market segments, AC and DC SWPS with water storage were sized for complete replacement of DWPs.

It was found that apart from market segments $3 \mathrm{AC}$ and DC SWPS, the other four systems with water storage have negative NPV thus are not profitable. On the other hand, replacing the water storage with DWP to be used on cloudy days has positive NPV for all the three market segments, thus is profitable. The PBP is

Table 6 Technical specifications of selected PV pumps [34-38]

\begin{tabular}{|c|c|c|c|c|c|c|}
\hline \multirow[t]{2}{*}{ Properties } & \multicolumn{2}{|c|}{ Big individually owned SWPS } & \multicolumn{2}{|c|}{ Shared SWPS } & \multicolumn{2}{|c|}{ Small individually owned SWPS } \\
\hline & $A C$ & DC & $A C$ & DC & $A C$ & DC \\
\hline Manufacturer & Shimge & Lorentz & Pedrollo & Lorentz & CLARKS & Veconte \\
\hline Model & SGT32-160/2.2 & PS4000 CS-F16-3 & HF20B-N & PS4000 CS-F42-10-1 & & VK 200-24 V \\
\hline Rated power (W) & 2200 & 3000 & 3000 & 4000 & 120 & 120 \\
\hline Efficiency (\%) & 72.8 & 53.4 & 82.4 & Variable & 54.5 & 40.8 \\
\hline Head (m) & 28 & 28 & 16.8 & 20 & 18 & 20 \\
\hline Flow rate $\left(\mathrm{m}^{3} / \mathrm{hr}\right)$ & 21 & 21 & 54 & 57 & 1.2 & 0.9 \\
\hline Max voltage $(\mathrm{V})$ & & 375 & & 375 & & \\
\hline Opt voltage $(\mathrm{V})$ & $>415$ & $>238$ & $>415$ & $>238$ & 230 & 24 \\
\hline Max current (A) & 7.12 & & 12 & & & \\
\hline Op. hours & & 20,000 & & & 20,000 & \\
\hline
\end{tabular}


Table 7 Cost of the main equipment considered in the profitability analysis (source: suppliers on the local market)

\begin{tabular}{|c|c|c|}
\hline \multirow[t]{2}{*}{ Item } & \multicolumn{2}{|l|}{ Rate } \\
\hline & FCFA & US\$ \\
\hline \multicolumn{3}{|l|}{ PV modules } \\
\hline $80 \mathrm{Wp}$ & 55,290 & 98 \\
\hline $200 \mathrm{Wp}$ & 113,430 & 201 \\
\hline $260 \mathrm{Wp}$ & 125,000 & 221 \\
\hline \multicolumn{3}{|l|}{ Inverter } \\
\hline $180 \mathrm{~W}$ & 55,000 & 97 \\
\hline $2500 \mathrm{~W}$ & 280,000 & 498 \\
\hline 3500 VA & 340,000 & 604 \\
\hline \multicolumn{3}{|l|}{ Pump } \\
\hline \multicolumn{3}{|l|}{ Solar pumps } \\
\hline \multicolumn{3}{|l|}{ AC pump } \\
\hline $3000 \mathrm{~W}$ & $1,200,000$ & 2132 \\
\hline $2200 \mathrm{~W}$ & 486,800 & 865 \\
\hline $120 W$ & 120,000 & 213 \\
\hline \multicolumn{3}{|l|}{ DC pump } \\
\hline $4000 \mathrm{~W}$ & $2,274,174$ & 4041 \\
\hline $3000 \mathrm{~W}$ & $1,800,880$ & 3200 \\
\hline $120 W$ & 150,000 & 267 \\
\hline \multicolumn{3}{|l|}{ Diesel pumps } \\
\hline $2600 W$ & 300,000 & 533 \\
\hline $5900 \mathrm{~W}$ & 700,000 & 1243 \\
\hline \multicolumn{3}{|l|}{ Water tank } \\
\hline \multicolumn{3}{|l|}{ Tank } \\
\hline $5 \mathrm{~m}^{3}$ & 190,000 & 338 \\
\hline $25 \mathrm{~m}^{3}$ & 982,500 & 1745.9 \\
\hline
\end{tabular}

7.1 years for market 3 DC SWPS/DWP, 10.1 years for market segment 2 AC SWPS/DWP and 11.3 years for market 1 AC SWPS/DWP.

Among the interest rates currently charged by MFIs in Burkina Faso on agricultural equipment loans, the
Table 9 Payback period (years) of the SWPS at different interest rates

\begin{tabular}{llll}
\hline SWPS systems & $\begin{array}{l}\text { PBP at } \\
9.5 \%\end{array}$ & $\begin{array}{l}\text { PBP at } \\
12 \%\end{array}$ & $\begin{array}{l}\text { PBP at } \\
14 \%\end{array}$ \\
\hline $\begin{array}{l}\text { Market segment 1 AC SWPS/ } \\
\text { DWP }\end{array}$ & 18.5 & $>20$ & $>20$ \\
$\begin{array}{l}\text { Market segment 2 AC SWPS/ } \\
\text { DWP }\end{array}$ & 15.0 & $>20$ & $>20$ \\
$\begin{array}{l}\text { Market segment 3 DC SWPS/ } \\
\text { DWP }\end{array}$ & 7.9 & 9.0 & 9.5 \\
\hline
\end{tabular}

suitable one for SWPS loan is $9.5 \%$ per year provided by Fédération des Caisses Populaires du Burkina (FCPB). At this interest rate, only market segment $3 \mathrm{DC}$ SWPS/DWP and in certain extent market segment 2 AC SWPS/DWP can be fully financed through loan without exposing the farmer to risks due to long PBP. Conclusively, there is no potential for SWPS with water storage for complete replacement of DWP to be financed through microloans. This is due to the lack of profitability or long PBP beyond 20 years. On the other hand, there is potential for microfinanced solar water pumping for market segment 2 and 3 if water storage is replaced with DWPs to be used for pumping on cloudy days.

However, the high cost of polyvinyl chloride (PVC) water tank in the local market and used in this study contribute enormously to increase the capital cost of the SWPS for all the market segments. More research could be conducted on technical, economical, environmental and societal aspects in order to compare the results of the current study with those of SWPS based on other forms of storage such as electric storage or water storage tanks built locally with steel or concrete. Besides, this study focused only on irrigation but other productive uses for which the excess of energy from the PV array can be used to maximise the profitability of the system will be investigated in further works.

Table 8 Summary of SWPS profitability analysis

\begin{tabular}{|c|c|c|c|c|c|}
\hline S/No & SWPS & Capital cost (US\$) & NPV (US\$) & PBP (years) & IRR (\%) \\
\hline 1 & Market segment 1 AC SWPS & $19,279.5$ & -3239.6 & $>20$ & $3.1 \%$ \\
\hline 2 & Market segment 1 DC SWPS & $22,461.8$ & -7985.3 & $>20$ & $0.4 \%$ \\
\hline 3 & Market segment 1 AC SWPS/DWP & 7745.9 & 3149.6 & 11.3 & $10.0 \%$ \\
\hline 4 & Market segment 2 AC SWPS & $42,535.8$ & $-14,678.3$ & $>20$ & $0.5 \%$ \\
\hline 5 & Market segment 2 DC SWPS & $49,003.0$ & $-19,638.2$ & $>20$ & $-0.3 \%$ \\
\hline 6 & Market segment 2 AC SWPS/DWP & $13,073.7$ & 7134.8 & 10.1 & $11.5 \%$ \\
\hline 7 & Market segment 3 AC SWPS & 1637.2 & 54.7 & $>20$ & $5.7 \%$ \\
\hline 8 & Market segment 3 DC SWPS & 1512.8 & 254.7 & 15.6 & $7.3 \%$ \\
\hline 9 & Market segment 3 DC SWPS/DWP & 630.5 & 956.3 & 7.1 & $19.5 \%$ \\
\hline
\end{tabular}




\section{Endnotes}

${ }^{1}$ Microfinance is defined as a range of financial services such as deposits, loans, payment services, money transfers and insurance that target poor households and their microenterprises [39].

${ }^{2}$ Productive use of energy refers to activities which use energy as an input to increase the income of an enterprise or a household [40].

${ }^{3}$ Capital city of Burkina Faso $70 \mathrm{~km}$ away from study but in same agroecological zone.

\section{Abbreviations}

CWR: Crop water requirement; DWP: Diesel water pump; FCPB: Fédération des Caisses Populaires du Burkina; IRR: Internal return rate; IWR: Irrigation water requirement; MFI: Microfinance institutions; NPV: Net present value; PBP: Payback period; PVC: Polyvinyl chloride; SWPS: Solar water pumping systems; WAEMU: West African Economic and Monetary Union

\section{Acknowledgements}

The authors acknowledge the support of the Technical University of Berlin (TU Berlin) and the Pan African University Institute of Water and Energy Sciences (PAUWES) inclunding Climate Change for their tehcnical support. They also thank the primary data collection team specially Idris Kamagade, Illy Ouangu, Lassane Sawadogo, Romeo Zongo, Serge Nda and the farmers in Korsimoro village.

\section{Funding}

This work was supported by the German Ministry of Education and Research (BMBF) in the framework of the Mikroklima West Africa Project.

\section{Authors' contributions}

DY conceived the study (problem statement, objectives and methodolgy), participated in its design, implementation and coordination. YA participated in the design of the study and have conducted the field survey. GC participated in the design of the study and its coordination. All authors read and approved the final manuscript.

\section{Ethics approval and consent to participate}

Not applicable

\section{Consent for publication}

All the authors read and agree to publish the article.

\section{Competing interests}

The authors declare that they have no competing interests.

\section{Publisher's Note}

Springer Nature remains neutral with regard to jurisdictional claims in published maps and institutional affiliations.

\section{Author details \\ ${ }^{1}$ Renewable Energies and Energy Efficiency Laboratory, Department of Electrical, Industrial and Energy Engineering, International Institute for Water and Environmental Engineering (2iE), Rue de la science 01, BP 594, Ouagadougou 01, Burkina Faso. 'Viva Energy International Limited, Plot 31 Pakwach Road, P. O. Box 460, Arua, Uganda. ${ }^{3}$ Microenergy International Gmbh, Potsdamer Str. 143, 10783 Berlin, Germany.}

Received: 13 September 2018 Accepted: 11 February 2019 Published online: 28 February 2019

\section{References}

1. United Nations (2017) Sustainable development goals - United Nations. http://www.un.org/sustainabledevelopment/sustainable-developmentgoals/. Accessed 25 May 2017

2. Kreft $S$, Eckstein $D$, Junghans L, Kerestan $C$, Hagen U, Kolboske B, Devarti L (eds) (2015) Global climatic risk index 2015: who suffers most from extreme weather event? weather-related loss events in 2013 and 1994 to 2013, 10th ed. Germanwatch e.V, Bonn

3. Hammill A, Matthew R, McCarter E (2008) Microfinance and climate change adaptation. IDS Bull 39(4):113-122. https://doi.org/10.1111/j.1759-5436.2008. tb00484.x

4. World Bank. (2015) Ending extreme poverty and sharing prosperity: progress and policies (October No. 3). World Bank Group: Policy Research Note

5. World Bank. (2016) World Bank Burkina Faso overview. http://www. worldbank.org/en/country/burkinafaso/overview. Accessed 5 Apr 2017

6. Chandel S, Nagaraju Naik M, Chandel R (2017) Review of performance studies of direct coupled photovoltaic water pumping systems and case study. Renew Sust Energ Rev 76:163-175. https://doi.org/10.1016/j. rser.2017.03.019

7. Arunendra K, Vilas R (2016) Performance investigations of solar water pumping system using helical pump under the outdoor condition of Nagpur, India. Renew Energy 97:737-745. https://doi.org/10.1016/j.renene.2016.06.021

8. Arunendra K, Vilas R (2017) Effects of total head and solar radiation on the performance of solar water pumping system. Renew Energy 118:919-927. https://doi.org/10.1016/j.renene.2017.11.004

9. Food and Agriculture Organization (2014) FAO Burkina Faso area inland water, 1961-2013 - knoema. https://knoema.com/atlas/Burkina-Faso/topics/ Land-Use/Area/Inland-water. Accessed 15 Apr 2017

10. Food and agriculture Policy decision analysis (Fapda) (2014) Burkina Faso country fact sheet on food and agriculture policy trends. Food and Agriculture Organization (FAO), Rome. http://www.fao.org/3/i3760e/i3760e. pdf. Accessed 15 Apr 2017

11. Fraiture C, Ndanga G, Sally H, Kabre P (2013) Pirates or pioneers ? Unplanned irrigation around small reservoirs in Burkina Faso. Agric Water Manag 131:212-220. https://doi.org/10.1016/j.agwat.2013.07.001

12. Ndanga Gaël (2011) Gestion de l'eau agricole et économie des usagers du barrage de Korsimoro ( Burkina Faso ) : État des lieux et pistes de réflexion, Mémoire de Master. Institut International d'Ingénierie de l'Eau et de l'Environnement, Ouagadougou

13. Sally H, Lévite H, Cour J (2011) Local water management of small reservoirs: lessons from two case studies in Burkina Faso. Water Alternatives 4(3):365-382

14. Geslain P (2014) Etude d' identification des technologies et acteurs microfinance verte en Afrique de I ' Ouest. Burkina Faso et Sénégal, Lyon

15. Evans AEV, Giordano M, Clayton, T (2012) Investing in agricultural water management to benefit smallholder farmers in Burkina Faso, AgWater Solutions Project country synthesis report, Colombo, Sri Lanka. International Water Management Institute (IWMI) ( IWMI Working Paper 149). https://doi. org/10.5337/2012.211

16. Mvondo Ayissi J (2010) Le developpement de I' irrigation a talembika : analyse de I ' echec d'un nouvel aménagement et de l'évolution de l'irrigation informelle. Institut International d'Ingénierie de l'Eau et l'Environment, Ouagadougou

17. Charan J, Biswas T (2013) How to calculate sample size requirements. Indian J Psycol Med 34(2):121-126. https://doi.org/10.4103/0253-7176.116232

18. Allen RG, Pereira LS, Raes D, Smith M (1998) Guidelines for computing crop water requirements. Food an Agricultural Organization (FAO) (FAO Irrigation and drainage paper 56), Rome. https://appgeodb.nancy.inra.fr/biljou/pdf/ Allen_FAO1998.pdf. Accessed 20 Apr 2017

19. Bouraima AK, Weihua Z, Chaofu W (2015) Irrigation water requirements of rice using CROPWAT model in Northern Benin. Int J Agricul Biol Eng 8(2): 58-64. https://doi.org/10.3965/j.ijabe.20150802.1290

20. Wang YM, Traore S, Kerh T (2009) Applying evapotranspiration reference model and rainfall contribution index for agricultural water management plan in Burkina Faso. AJAR 4(12):1493-1504

21. Jenkins $T$ (2013) Designing solar water pumping systems for livestock. New Mexico State University (Circular 670), New Mexico. https://aces.nmsu.edu/ pubs/_circulars/CR670.pdf. Accessed 22 Apr 2017

22. Nisha P, Ramani K (2013) Design and implementation of solar powered water pumping system. I J C Sci 2(2):272-278

23. Doorenbos J, Pruit WO (1977) Guidelines for predicting crop cater requirement. Food and Agricultural Organization (FAO) (FAO Irrigation and drainage paper 24), Rome. http://www.fao.org/3/a-f2430e.pdf. Accessed 22 Apr 2017

24. CLIMATEMPS (2009). Climate and temperature. http://www.burkina-faso. climatemps.com/sunlight.php. Accessed 1 Aug 2017

25. Bhattacharyya SC, Palit D, Bhattacharyya SC, Pali D (eds) (2014) Mini-grids for rural electrification of developing countries. Springer, Geneva 
26. Lin CH, Hsieh WL, Chen CS, Member S, Ku TT, Tsai CT (2012) Financial analysis of a large scale photovoltaic system and its impact on distribution feeders. IEEE Trans Ind Appl 47:1884-1891

27. Hsu C, Chen C, Korimara R (2012) The photovoltaic generation system impact on the energy demand of a small island and its financial analysis. Energy Procedia 14:411-417. https://doi.org/10.1016/j.egypro.2011.12.95

28. Hosenuzzaman M, Rahim NA, Selvaraj J, Hasenuzzaman M (2015) Global prospects, progress, policies, and environmental impact of solar photovoltaic power generation. Renew Sust Energ Rev 41:284-297. https:// doi.org/10.1016/j.rser.2014.08.046

29. Treephak K, Thongpron J, Somsak D, Saelao J, Patcharaprakoto N (2015) An economic evaluation comparison of solar water pumping system with engine pumping system for rice cultivation. JJAP 54:1-7

30. SEEP 2014 Responsible finance market overview: Burkina Faso. Retrieved from https:/www.microfinancegateway.org/sites/default/files/mfg-en-paperresponsible-finance-market-overview-burkina-faso-2014.pdf

31. Doorenbos J, Kassam A (1979) Crop yield response to water. Food and Agricultural Organization (FAO) (FAO irrigation and drainage Paper 33), Rome. http://www.fao.org/3/i2800e/i2800e.pdf. Accessed 23 Apr 2017

32. BCEAO 2017. Central Bank of West African States. http://www.bceao.int/. Accessed 1 July 2017

33. Program WF (2016) Financial inclusion P4P experiences in systemic change. Program WF, Rome. https://m.wfp.org/sites/default/files/P4PSystemic ChangeFactSheets-7-Financiallnclusion_11 October_Advance Draft.pdf. Accessed 24 Apr 2017

34. SHIMGE. http://www.shimge-pump.com. Accessed 4 Apr 2017

35. LORENTZ. http://www.lorentz.de. Accessed 4 Apr 2017

36. PEDROLLO. http://www.pedrollo.co.uk. Accessed 4 Apr 2017

37. CLAKE ELECTRIC. http://www.clake-electric-water-pump-litre.com. Accessed 4 Apr 2017

38. VACKSON. http://www.vackson-pumps.com. Accessed 4 Apr 2017

39. Helms B (2006) Access for all consultative group to assist the poor. Consulting group for Assisting the Poor, Washington DC Retrieved from http://www.cgap.org/sites/default/files/CGAP-Access-for-All-Jan-2006.pdf

40. Brüderle A, Attigah B, Bodenbender M (2011) Productive use of energyPRODUSE, a manual for electrification practitioners. GIZ,Eschborn. https:// www.giz.de/fachexpertise/downloads/giz-eueipdf-en-productive-usemanual.pdf. Accessed 1 Aug 2017

Ready to submit your research? Choose BMC and benefit from:

- fast, convenient online submission

- thorough peer review by experienced researchers in your field

- rapid publication on acceptance

- support for research data, including large and complex data types

- gold Open Access which fosters wider collaboration and increased citations

- maximum visibility for your research: over $100 \mathrm{M}$ website views per year

At $\mathrm{BMC}$, research is always in progress.

Learn more biomedcentral.com/submissions 